\title{
Suzhou's Building of a Paradigm in Global Energy Transtion-Driven Urban Development: The Contents and Pathways
}

\author{
Lin-Yu WANG ${ }^{1, a}$, Qiang SUN ${ }^{1, b}$, Rui-Xin $\mathrm{CHEN}^{1, \mathrm{c}}$ and Wei-Yang $\mathrm{LI}^{1, \mathrm{~d}}$ \\ ${ }^{1}$ State Grid Energy Research Institute, Future Technology Park, Changping, Beijing, China \\ awanglinyu@sgeri.sgcc.com.cn, bsunqiang@sgeri.sgcc.com.cn, 'chenruixin@sgeri.sgcc.com.cn
}

Keywords: Energy Transition, Paradigm, Urban, Pathway, Content.

\begin{abstract}
Suzhou's building of a paradigm in global energy transition-driven urban development is a pioneering and hard work. This paper introduces the main contents and the pathways on what and how the Suzhou will build the paragidm city in energy transition, the contents give the details on the "five models" and the pathways introduce two parallel ways and their intermediate stages. The main output is a strategy design of the urban energy transtion plan that explore a path in which energy transition drives urban development and urban energy development further leads the energy transition in China.
\end{abstract}

\section{Introduction}

Energy is the base of social and economic development, also energy activities results in a host of problems, among which the environmental pollution and climate change are the most serious ones [1] At the UN Sustainable Development Summit on September 26, 2015, Chinese President Xi Jinping proposed a discussion on establishing a global energy interconnection to facilitate efforts to meet global power demand with clean and green alternatives, and proposed the "Chinese initiative" for international energy transition [2]. China signed "Paris Agreement" and has played an extremely constructive leadership role as a "responsible great country", released a strong signal of its transition on energy towards a low-carbon and climate-catering economy [3]. The nation has set clear goals of controlling total energy and coal consumption during the " $13^{\text {th }}$ Five-Year Plan", and the 2016 annual urban development plan takes extra efforts on highlighting peominent aspects [4]: adopting the indexes clearly reflecting the concepts of the innovative, coordinative, green, open and shared development and exploring the way to enhance the urbanization quality. In fact, the government has set limiation to control the total energy and coal consumption.

The energy consumption structure of Suzhou is dominated by coal. Total carbon emission stays at a high level. Thus it is pressing to adjust the high-carbon energy structure. In 2015, total energy and coal consumptions of largescale industries in Suzhou exceeded 80 million tons and 54 million tons standard coal equivalent, respectively. Coal takes over $66 \%$ of large-scale industry energy consumption in Suzhou. Carbon emission totaled 152 million tons, with the intensity of about 1.04 tons/10,000 RMB GDP [5]. Suzhou faces huge pressure on the control of total energy and coal consumption to reduce emission.

The Suzhou's energy transition plan is proposed to solve the problems and make an example for smoothly energy transition, the main contents and the pathways that will be shown in this paper shown up how the ideas will be performed.

The left of the paper are organized in the following sequence: the second section introduces the main contents of the energy transition plan, the pathways of the plan are explained in section three, and the conclusion is presented in section four.

\section{Main Contents of the Energy Transition Plan}

The energy transition plan focus on five orientations, and create a Suzhou sample in which energy transition drives comprehensive urban development and urban energy transition guide national energy transition, which can be concluded as "five models". 


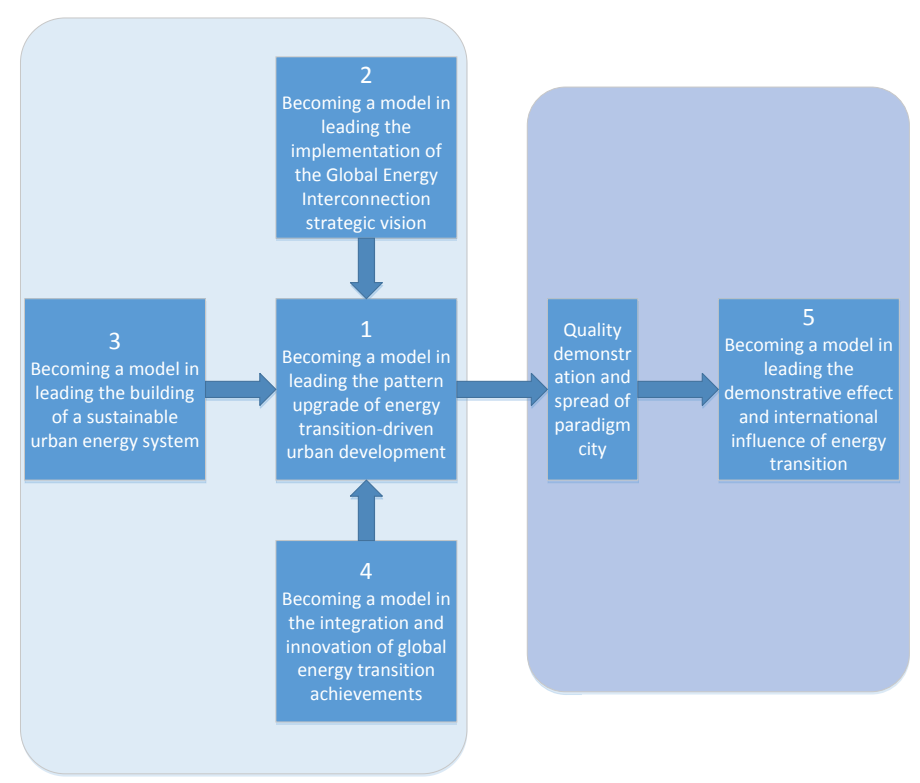

Fig.1 the logical structure of the five models

\section{Upgrading Of Energy Transition-Driven Urban Development}

The first setp of upgrading of energy transition and its resulting of urban development is to rethink the relationship between energy and city. In the respective of mode of energy thinking, the previous perspective on energy is to consider energy in the energy system and pay much attation to energy security, the new consideration will take a strategic and overview on the relationships between energy and city, and pay more attenation to energy transition-driven urban development. In regarding of the way energy works, Suzhou will change from the manner of mainly paying attention to the way that energy drives urban economy development to the way that energy transition drives economy, society, environment, culturel, management, and competitive development as well as improvement of residents' living quality in the city. From energy allocation's point of view, Suzhou will change the energy allocation mode from coal transport, high pollution, high carbon emission and local balance to clean, low carbon, and trans-regional power balance. From constraints point of view, Suzhou will evolve from the soft constraints mode of prioritizing economic growth over energy and environmental objectives to the hard constraint mode of strictly guiding and forcing the urban and energy transformation with energy and environmental objectives. Suzhou will also reshape the energy management mode into a mode in which energy transition and urban development are coupled, and all types of energy being deployed in coordination. From the angle of energy management, the new urban management mode will feature high alignment between energy transition and comprehensive urban development as well as joint the development of various energy sources.

The second setp is to carry forward innovative practices for comprehensive development of energy transition driven city. First, the transition must be performed in objective-driven approaches, with the guideline of "safety, saving, cleanness, low carbon, economy and general preference”, Suzhou will set rigorous energy constraint objectives and to guide and drive the upgrading of urban and energy. Second, it must persist in implementation of pilot projects, the policy offer chance for the realization of innovative and demonstrative projects. Third, persisting in the drive with mechanism-policy portfolio, Suzhou will persist in the innovations of market mechanism, government regulation mechanism as well as social governance mechanism, and persist in the comprehensive effect of policy portfolios such as target constraining, planning as guide, and culture renovation. Forth, the transition must be supported by high-tech and its related industries. Suzhou will forge an entire industrial chain combining research, development and pilot of energy technologies with strategic emerging industries to support Suzhou's building of advanced industrial bases and technological innovation center. Finally, it must be pushed by innovaiton of energy management. Suzhou will strengthen top-level design for energy transition and comprehensive urban development. 


\section{Implementation of the Global Energy Interconnection}

Considering the fact that for most of the countries and cities that the energy sources, especially the clean energy that can be develped on a large scale, are far away from the demand center [1], it is reasonable to have clean energy been transfered with ultra-high-voltage (UHV) grids, such a global energy interconnection transmits primarily clean energy, connects large clean energy bases with various distributed power generation facilities, and delivers clean energy to different types of end-users. It is a widespread, highly deployable, safe, reliable, green, and low-carbon global energy distribution platform.

Suzhou is planned to build a big receiver-side clean energy consumption demonstration area as part of the Global Energy Interconnection (GEI) strategy. This pilot project consists of three main parts: first, with the excellent power grid infrastructure, Suzhou will further build a world-leading urban power grid backed by UHV AC/DC hybrid power source, support the transmission of hydroelectric power from the southwestern region and wind power from the northwest region to the Yangtze River Delta. Second, Suzhou will be a pilot region on the construction of a series of key UHV projects, such as the UHV GIL cross-river pipeline corrider with extraordinary long distance, the highest voltage level and the largest transimission capacity, the $1000 \mathrm{kV} \mathrm{UHV} \mathrm{AC} \mathrm{transformer}$ station with largest size, highest transformation capacity and strongest power supply capacity in the world. Third, Sozhou is planned to be a pilot region on the construction of a robust power grid with both high reliability and high flexibility, Suzhou will build the world's first source-grid-load friendly interaction system with large scale, pilot the $500 \mathrm{kV}$ unified power flow controller (UPFC), millisecond-grade large-capacity dynamic inactive compensation project and other advanced technologies, and build a robust grid construction mode with large load with flexible curability of failure, flexible controllability of flow and flexible adjustment of resources.

\section{Building of a Sustainable Urban Energy System}

A sustainable urban energy system is with smart energy system as core, takes the development of energy technoligies and industries, the transition of the way energy consumption in industry, building, transportation and lifestyle, the evoluation of energy management into account. First, Suzhou is building smart energy system based on intelligent information and communication technologies (ICT), the system actively integrates a high proportion of clean energy from the imported electricity. Second, Suzhou will persist in technical drive and industrial support, and establish the clustering and collaboration of energy technologies and industry as a mighty support for the sustainable urban energy system. Third, Suzhou will drive the transformation and upgrade of urban manufacturing, building, transportation, lifestyle through energy transition. Finally, Suzhou will perform urban energy management innovation to break the boundary among each kind of energy and its management department.

\section{Integration and Innovation of Global Energy Transition Achievements}

Innovation in technologies make tangible improvement in energy transition, and cooperation in technologies will speed up the development of the corresponding area. Suzhou plans to be a pilot area, where poineer the application, implementation of innovative projects, leading technologies, innovative equipment and pilot projects.

Suzhou will continuously encourage new thoughts and new concepts for global energy transition, assemble a batch of pioneering and pilot projects for energy transition, nourish and incubate a batch of international innovative energy technologies and realize collaborative development of energy products and industrial clusters. In a word, Suzhou is open for all the advanced technologies on energy transition, it will create environment for the introduction, adsoption of solutions, and furthermore generate comprehensive solutions. The necessary policy and funds support is on the schedule for the bring-in and application of technologies.

\section{Demonstrative Effect and International Influence}

Brand promotion starts with the eatablishment of the brand. The energy transition happening in 
Suzhou is a model in leading the demonstrative effect, thus it has international influence. As a place for the concept origination, a place for the concept propagation, a place for the technical promotions, a place for the product applications, and a place for industrial clustering for global energy transition, Suzhou will continuously provide the world energy transition with a high-end exchange platform, a pilot platform for product and technology and a platform for international development of the equipment industry.

This is to say, Suzhou will build a mix of world-famous international platforms for cooperation and exchange in energy transition; Suzhou will continuously attract innovative and pioneering projects to settle down and assemble technologies, products and industries; Suzhou will propel the evolution of energy technology, equipment and industry in the direction towards cluster, collaboration, brand and internationalization.

Suzhou will actively participate in global energy governance, carry out global energy cooperation and competition over a broad range, exert the leadership as a typical city of global energy transition, and become a city advocating and practicing the concept of global sustainable energy development. In a word, Suzhou is making "Paradigm in Global Energy Transition" a new name card of the city.

\section{Pathways of the Energy Transition Plan}

In building into the paradigm of global energy transition, Suzhou will focus on urban energy transition, and explore a path in which energy transition drives urban development and urban energy development further leads the energy transition in China and the world. Fig.2 shows the pathways of the strategy.

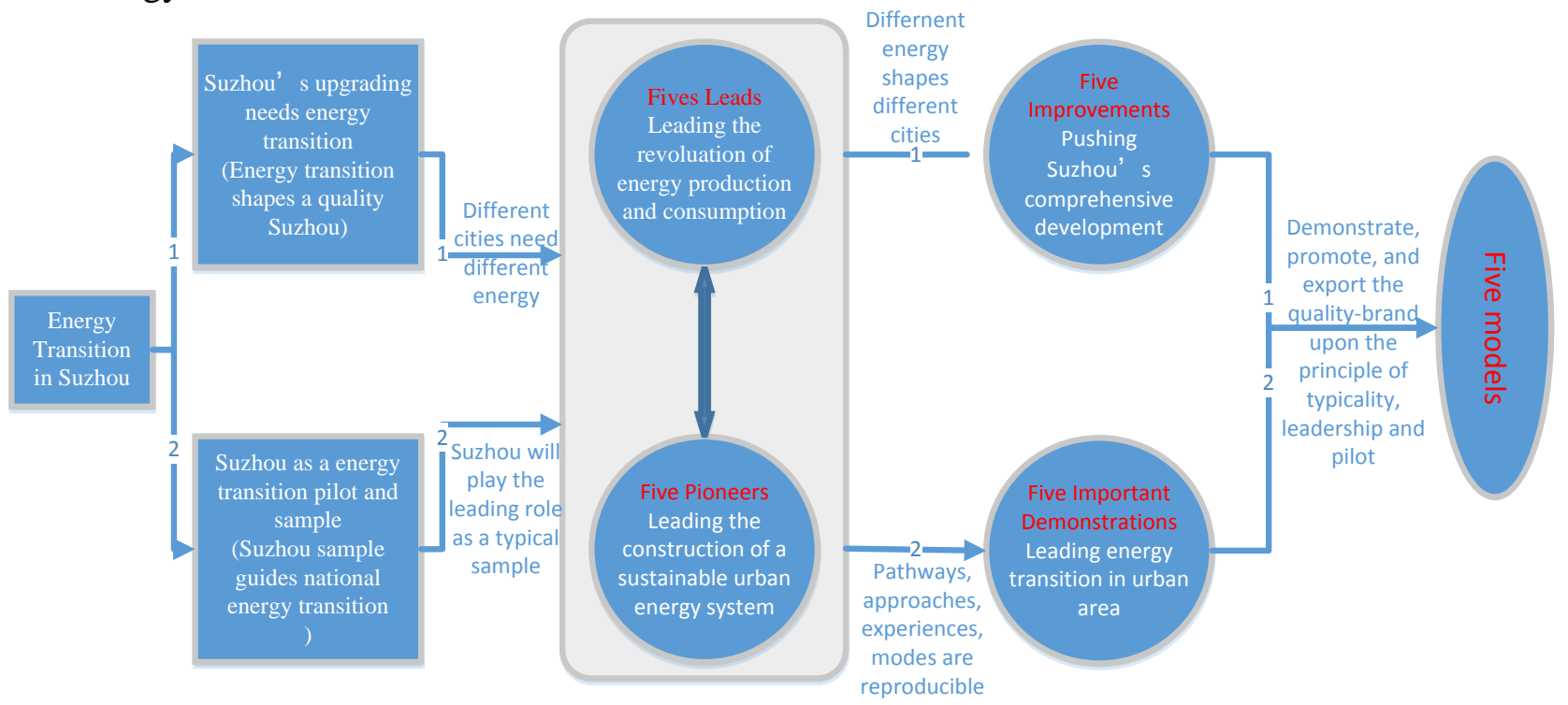

Fig.2 the strategic pathways of the realization of energy transition and afterwards in Suzhou

\section{Energy Transition Shapes a Quality Suzhou}

Out of the need to upgrade quality through energy transition, Suzhou will fully tap the potential of comprehensive urban development through energy transition and explore a strategic pathway of building a quality Suzhou through energy transition, with the core of guiding the revolution of energy production and consumption to land in the city ("Five Leads"), with the way of guiding the construction of a sustainable urban energy system ("Five Pioneers"), and with the scale of driving comprehensive development ("Five Improvements").

The "Five Leads" respesents the leading of energy transition in the five aspects of the "four revolution, one cooperation" strategy. The details can be seen in Tab. 1 . 
Tab.1 the Five Leads and their details

\begin{tabular}{|c|l|}
\hline $\begin{array}{c}\text { In terms of } \\
\text { Energy } \\
\text { consumption }\end{array}$ & $\begin{array}{l}\text { 1, set strict energy transition goals, control energy and coal consumption; 2, guide } \\
\text { and propel indutrial restructuring, optimize the energy consumption structure by } \\
\text { electricity replacement; 3, mutual supplement between various kinds of energy; } \\
\text { increase energy efficiency by comprehensive energy saving in industry, } \\
\text { buildings, transportation and residents lives. }\end{array}$ \\
\hline Energy supply & $\begin{array}{l}\text { 1, interregional balance by UHV; 2, local distributed renewable energies; 3, } \\
\text { concertrated efficient clean utilization of coal and other fossil energy, increase the } \\
\text { proportion of coal consumption in power generation. }\end{array}$ \\
\hline $\begin{array}{c}\text { Energy } \\
\text { technologies }\end{array}$ & $\begin{array}{l}\text { 1, application, implementation and operation of innocative energy transition } \\
\text { projects, leading technologies, innovative equipments and pilot projects; 2, } \\
\text { actively carry forward the fusion and the innovation of energy transition } \\
\text { achievements; 3, refine policy support and institutional assurance, provide } \\
\text { platforms, strengthen the commercialization and the industrialization of energy } \\
\text { technologies. }\end{array}$ \\
\hline $\begin{array}{c}\text { Energy } \\
\text { management }\end{array}$ & $\begin{array}{l}\text { 1, reshape the energy management pattern, strengthen top-level design, } \\
\text { comprehensive collaboration, coordinated planning and integration with urban } \\
\text { sevelopment; 2, refine planning, tax incentives, preferential policy and technical } \\
\text { reform to carry forward the revolution of energy; 3, market-oriented energy }\end{array}$ \\
\hline $\begin{array}{c}\text { Cooperation on } \\
\text { energy transition }\end{array}$ & $\begin{array}{l}\text { 1, create high-level international cooperation and communication platforms; 2, } \\
\text { strengthen intelligence cooperation, technical cooperation, policy cooperation } \\
\text { and market cooperation; 3, encourage key equipments and new energy industry go } \\
\text { abroad. }\end{array}$ \\
\hline
\end{tabular}

The "Five Leads"shows the pathway from the angle of energy revoluation, it is straightforward to build a sustainable urban energy system, which results in "Five pioneers", which is listed in Tab. 2, the "Five Pioneers" is tightly connected with "Five Leads" , thus with the realization of "Five Pioneers", it is easily to achieve "Five Leads".

Tab.2 the Five Pioneers and the details

\begin{tabular}{|c|l|}
\hline $\begin{array}{c}\text { In terms of } \\
\begin{array}{c}\text { integrate high proportion of } \\
\text { clean energy through } \\
\text { electricity import }\end{array}\end{array}$ & $\begin{array}{l}\text { Sustainable urban energy supply system; 1,000kV GIL; pivot } \\
\text { transformer station; integrating local network into the Eastern China } \\
\text { UHV AC ring grid; large scale source-grid-load friendly interaction } \\
\text { system, unified power flow controller }\end{array}$ \\
\hline $\begin{array}{c}\text { establish urban smart energy } \\
\text { systems }\end{array}$ & $\begin{array}{l}\text { integrate the energy system and advanced information technologies } \\
\text { in depth, actively drive the development of "Internet+" smart energy, } \\
\text { implement smart upgrade of energy supply and consumption } \\
\text { infrastructures, and accelerate the smart evolution of urban energy in } \\
\text { all areas }\end{array}$ \\
\hline $\begin{array}{c}\text { realize joint development in } \\
\text { energy technologies and } \\
\text { industrial clusters }\end{array}$ & $\begin{array}{l}\text { forge an entire industrial chain combining research, development, } \\
\text { pilot and application of energy technologies and equipment. }\end{array}$ \\
\hline $\begin{array}{c}\text { comprehensively upgrade } \\
\text { urban energy consumption } \\
\text { sectors }\end{array}$ & $\begin{array}{l}\text { employ the market mechanism to promote energy efficiency, energy } \\
\text { saving and emission reduction }\end{array}$ \\
\hline $\begin{array}{c}\text { drive comprehensive energy } \\
\text { transition with innovated } \\
\text { urban energy management }\end{array}$ & $\begin{array}{l}\text { build an urban energy information management platform, establish } \\
\text { an entire information chain covering supply, distribution and } \\
\text { consumption, refine the energy statistics and monitoring system }\end{array}$ \\
\hline
\end{tabular}


Suzhou will benifit from the energy transition, and Suzhou's development will be pushed to realize "Five Improvements". The "Five Improvements" concerns on the comprehensive development of the city, which includes the cconomic, ecological, living quality, mangement, and competitiveness of the city. The details are shown in Tab. 3.

Tab.3 the Five Improvements and the details

\begin{tabular}{|c|l|}
\hline $\begin{array}{c}\text { In terms of } \\
\text { economic } \\
\text { development } \\
\text { quality }\end{array}$ & $\begin{array}{c}\text { coordinated development of economic, social and environmental areas as well as } \\
\text { innovative driving; }\end{array}$ \\
\hline $\begin{array}{c}\text { ecological } \\
\text { progress }\end{array}$ & $\begin{array}{l}\text { continue the mutual promotion between energy transition and green GDP; } \\
\text { actively carry forward interregional collaboration in environmental governance } \\
\text { with the extensive resource distribution as the support, effectively curb fog, and } \\
\text { prevent pollutant emissions; guide and drive urban development transformation } \\
\text { with the constraining objectives of energy transition }\end{array}$ \\
\hline $\begin{array}{c}\text { living quality of } \\
\text { ruzhou's }\end{array}$ & $\begin{array}{l}\text { energy kindles a quality life; build new business format and mode supported by } \\
\text { the modern energy system; build new business format and mode supported by the } \\
\text { modern energy system; propel all stakeholders to participate in the joint } \\
\text { construction and sharing }\end{array}$ \\
\hline level & $\begin{array}{l}\text { propel the innovation and upgrade of urban development concepts, governance } \\
\text { technologies and transition models; refine and forge a highlevel urban energy } \\
\text { management system; enhance the urban strategic development and explore } \\
\text { effective mode to drive comprehensive development with energy transition; } \\
\text { improve the planning level, and carry forward the integration, mutual complement } \\
\text { and linkage between different plans; lift the urban smart development level }\end{array}$ \\
\hline $\begin{array}{c}\text { sustainable } \\
\text { competitiveness }\end{array}$ & $\begin{array}{l}\text { promote the urban competitive strengths driven by innovations and supported by } \\
\text { high-level industrial structure; deepen the innovation of energy technologies, } \\
\text { foster strategic emerging energy industries, develop new energy formats and } \\
\text { modes, and support continuous enhancement of competitive strengths }\end{array}$ \\
\hline
\end{tabular}

\section{Suzhou’s Sample Guides National Energy Transition}

From the perspective of becoming a sample in energy transition, Suzhou will fully play its typical role and explore a strategic pathway of guiding the transformation as an example of change, with the core of guiding the revolution of energy production and consumption in the city ("Five Leads"), with the ways of guiding the construction of a sustainable urban energy system ("Five Pioneers"), and with the scale of forming important demonstrations ("Five Important Demonstrations"), which is listed in Tab.4. 
Tab.4 the Five Important Demonstrations and the details

\begin{tabular}{|c|c|}
\hline In terms of & Details \\
\hline $\begin{array}{l}\text { Creation of "five } \\
\text { places" }\end{array}$ & $\begin{array}{l}\text { attact innovative projects, advanced technologies, most efficient service } \\
\text { modes; build itself into a place for the concept origination, concept } \\
\text { propagation, technical promotions, product applications, and industrial } \\
\text { clustering for global energy transition }\end{array}$ \\
\hline $\begin{array}{l}\text { Energy } \\
\text { transition-driven } \\
\text { urban development }\end{array}$ & $\begin{array}{l}\text { adhere to "safety, saving, cleanness, low carbon, economy and general } \\
\text { preference" }\end{array}$ \\
\hline GEI strategy & $\begin{array}{l}\text { provide a reference in receiving a large proportion of clean energy on a large } \\
\text { scale from outside; bearing the high-intensity load, and realizing optimal } \\
\text { resource distribution over a broad range; provide a reference in driving } \\
\text { significant breakthroughs of key technologies for the Global Energy } \\
\text { Interconnection initiative }\end{array}$ \\
\hline $\begin{array}{c}\text { sustainable urban } \\
\text { energy system }\end{array}$ & as been described in Tab.2 \\
\hline $\begin{array}{l}\text { integrating and } \\
\text { innovating energy } \\
\text { transition } \\
\text { achievements }\end{array}$ & $\begin{array}{l}\text { provide a usable reference in absorbing global energy transition achievements } \\
\text { and realizing in-depth fusion of energy transition technologies, products and } \\
\text { industries; comprehensive energy solutions based on actual conditions of } \\
\text { cities. }\end{array}$ \\
\hline
\end{tabular}

\section{Conclusions}

This paper introduces the main contents and the pathways of the energy transition plan of Suzhou. The logical structure of the five models is introduced first and then the details of the five models and the pathways to get the five models are presented. It is clear that the pathways consist of two directions: one is to speed up the development of urban and shapes a quality Suzhou, the other is to set typical example on energy transition for the other cities in China. The final goal of energy transition is clear: for the comprehensive and sustainable development of the nation, especially the urban areas.

\section{References}

[1] Zhenya Liu, Global Energy Interconnection, first ed., Elsevier, New York, 2016.

[2] President $\mathrm{Xi}$ proposes to discuss and construct global energy interconnection, information on http://www.people.com.cn [Chinese version]

[3] China signs Paris Agreement on climate change, information on http://news.xinhuanet.com.

[4] Chinese society for Urban Studies, $6^{\text {th }}$ Annual report on low-carbon eco-city, first ed., China architecture and building Press, Beijing, 2016.

[5] Suzhou Statistical Yearbook 2015, information on http://www.sztjj.gov.cn. 